\title{
EUS in the diagnosis of pathologically undiagnosed esophageal tuberculosis
}

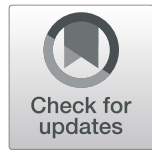

Rong Zhu' ${ }^{1}$ Yonghua Bai', Yuankun Zhou', Xingguo Fang ${ }^{1}$, Kui Zhao', Biguang Tuo ${ }^{1}$ and Huichao Wu ${ }^{\text {* }}$

\begin{abstract}
Background: Esophageal tuberculosis (ET) is relatively rare, and the diagnosis is challenging. The aim of this study was to evaluate the clinical features of ET and highlight the role of endoscopic ultrasonography (EUS) in the diagnosis of pathologically undiagnosed ET.

Methods: We retrospectively analysed the clinical features, radiological performances, conventional endoscopic appearances, EUS features, treatment and outcomes of pathologically undiagnosed ET between January 2011 and December 2018. All 9 patients failed to be diagnosed by at least two repeated biopsies (such as routine biopsy, multipoint or deep biopsy, and even or EUS-guided fine-needle aspiration (EUS-FNA)).

Results: Nine patients (66.7\% female) with a mean age of 45 years (range 29-59) complained of retrosternal pain or discomfort, or (and) dysphagia. Esophagoscopy demonstrated protruding lesions in the mucosa with central ulcers or erosion in five patients, submucosal bulges with smooth surfaces in one patient, submucosal bulges with diverticula in one patient, ulcers with suspicious fistula formation in one patient, and multiple ulcers in one patient. None of the patients received confirmed histopathological or bacteriological diagnoses by repeated biopsies. However, they were first suspected to have ET based on EUS examination. Because EUS found some characteristic ultrasonographic changes, which were very helpful for the diagnosis of ET when combined with clinical manifestations, the patients subsequently received diagnostic antituberculosis therapy. Finally, the patients recovered or improved with follow-up times ranging from 3 to 10 months.

Conclusions: EUS could help in the diagnosis of ET on basis of EUS features like poorly defined esophageal wall structure, enlarged paraesophageal or mediastinal lymph nodes, hypoechoic lesions of esophageal wall that are linked to the enlarged paraesophageal lymph nodes. However all attempts should be made to obtain histological or microbiological diagnosis.
\end{abstract}

Keywords: Esophageal tuberculosis (ET), Endoscopic ultrasonography (EUS), Retrosternal pain, Dysphagia

\section{Background}

Esophageal tuberculosis (ET) is relatively rare, accounting for $<0.2 \%$ of all tuberculosis (TB) patients [1-3]. The clinical manifestations are often not specific, including mucosal or submucosal eminence lesions, ulcer, fistula [4], and others [5]. A definite diagnosis of ET requires finding acid-fast bacilli or caseous necrotizing granuloma

\footnotetext{
* Correspondence: 18076207034@163.com

'Department of Gastroenterology, Affiliated Hospital, Zunyi Medical University, Zunyi 563003, China

Full list of author information is available at the end of the article
}

[6], which is challenging in clinical practice. Therefore, patients with ET are often misdiagnosed or receive a delayed diagnosis. Endoscopic ultrasonography (EUS) can show the shape and echogenicity features of the lesion, its relationship with the esophageal wall, the esophageal wall and extramural changes, such as extramural lymph nodes, and EUS may also provide a cytological and pathological diagnosis by endoscopic ultrasonographyguided fine-needle aspiration (EUS-FNA) [7], or exclude lesions such as cancer. Therefore, EUS has unique value in the diagnosis and differential diagnosis of ET, especially

(c) The Author(s). 2020 Open Access This article is licensed under a Creative Commons Attribution 4.0 International License, which permits use, sharing, adaptation, distribution and reproduction in any medium or format, as long as you give appropriate credit to the original author(s) and the source, provide a link to the Creative Commons licence, and indicate if changes were made. The images or other third party material in this article are included in the article's Creative Commons licence, unless indicated otherwise in a credit line to the material. If material is not included in the article's Creative Commons licence and your intended use is not permitted by statutory regulation or exceeds the permitted use, you will need to obtain permission directly from the copyright holder. To view a copy of this licence, visit http://creativecommons.org/licenses/by/4.0/. The Creative Commons Public Domain Dedication waiver (http://creativecommons.org/publicdomain/zero/1.0/) applies to the data made available in this article, unless otherwise stated in a credit line to the data. 
for patients who have not been confirmed by repeated biopsies.

Here, we retrospectively analysed the clinical features and endoscopic and EUS features of ET that failed to be pathologically diagnosed by routine biopsy, multipoint or deep biopsy, and even EUS-FNA in our hospital and summarized the EUS features and their value in the diagnosis of ET. We believe that these features will be significant to clinical work.

\section{Methods}

Nine cases of pathologically undiagnosed ET were identified between January 2011 and December 2018 in the Department of Gastroenterology at the Affiliated Hospital of Zunyi Medical University. These patients did not receive confirmed diagnoses by at least two repeated biopsies (such as routine biopsy, multipoint or deep biopsy, and even EUS-FNA). The patients were retrospectively reviewed for their clinical features, radiological performances, conventional endoscopic appearances, EUS features, treatment and outcomes. All 9 patients were first suspected to have ET based on EUS examination, and when combined with the clinical manifestations, the patients all received diagnostic antituberculosis therapy. Ultimately, the diagnosis of ET was confirmed because the patients recovered or improved, with follow-up times ranging from 3 to 10 months. EUS was performed using a miniature ultrasonic probe (UM-2R $12 \mathrm{MHz}$; Olympus, Tokyo, Japan) with a circular scanning ultrasound endoscope (UE260AL5, Olympus, Tokyo, Japan) and a longitudinal scanning ultrasound endoscope (UCT240-AL5, Olympus, Tokyo, Japan). We usually used a miniature ultrasonic probe to observe the changes in the esophageal wall and then used a circular or longitudinal scanning ultrasound endoscope to observe the far-field, such as lymph nodes and surrounding tissues and organs outside the esophageal wall.

\section{Results}

\section{Clinical features of pathologically undiagnosed ET}

Nine patients (66.7\% female) with a mean age of 45 years (range 29-59) complained of retrosternal pain or discomfort, or (and) dysphagia, with durations ranging from 2 to $9 \mathrm{wk}$. Four patients had a history of pulmonary tuberculosis $(44.4 \%)$. Only two patients had an increased erythrocyte sedimentation rate (ESR) (normal reference value of ESR: $0-15 \mathrm{~mm} / \mathrm{h}$ for males and $0-20$ $\mathrm{mm} / \mathrm{h}$ for females) (22.2\%), but the PPD test or TSPOT. TB were all positive (PPD test was performed in patients before 2014 and T-SPOT. TB was performed after 2015 in our hospital). Chest CT showed secondary pulmonary tuberculosis in two cases (22.2\%), pulmonary fibrotic foci in six cases (66.7\%) and multiple calcifications in one case. Eight cases (in case No. 8, biopsy was not performed because the submucosal bulge was small and the surface was smooth) were confirmed by repeated biopsies (3 cases with routine biopsy and deep excavation, 4 cases with routine biopsy and multipoint biopsy, and one case with routine biopsy and EUSFNA), but the pathological findings were only chronic or acute inflammation, and no specific caseous necrotizing granuloma or acid-fast staining positive bacilli was found. (Table 1).

\section{Esophagoscopy findings and EUS features of pathologically undiagnosed ET}

Of all 9 patients, ET involvement of the esophagus was observed in the middle part in seven cases $(77.8 \%)$, in the lower part in only one case (11.1\%), and in the upper part in only one case (11.1\%). The sizes of the main lesions ranged from $0.3 \times 0.5 \mathrm{~cm}$ to $2.5 \times 3.0 \mathrm{~cm}$. Esophagoscopy demonstrated protruding lesions in the mucosa with central ulcers (Fig. 1. 1-3 $\mathrm{a}$ and $\mathrm{b}$ ) or erosion (Fig. 2. 1-2 a and b) in five cases (55.6\%), submucosal bulge with smooth surface in one case (11.1\%) (Fig. 3. a and b), submucosal bulge and diverticulum (confirmed by esophagography) in one case (11.1\%) (Fig. 4. a-c), ulcer with suspicious fistula formation (with a small amount of bubbles and fluid in the mediastinum around the esophagus on chest CT) in one case (11.1\%) (Fig. 5. a-c), and multiple ulcers in one case (11.1\%) (Fig. 6. a and b). (Tables 1, 2 and Figs.1, 2, 3, 4, 5 and 6).

Furthermore, the EUS features of pathologically undiagnosed ET were carefully observed and analysed. The results showed that all patients had thickening and a poorly defined esophageal wall structure (100.0\%), and the partial esophageal adventitia was interrupted; eight patients had one or more enlarged paraesophageal lymph nodes (88.9\%), and four patients had scattered calcifications in the esophageal hypoechoic lesions or paraesophageal lymph nodes $(44.4 \%)$. Very interestingly, in four patients (cases No. 2, 4, 6 and 8), accounting for $44.4 \%$ of the patients, the lesions of the esophageal wall were linked to enlarged paraesophageal lymph nodes, which implies that tuberculosis of the paraesophageal nodes spreads directly to the esophagus wall. (Table 2 and Figs.1, 2, 3, 4, 5 and 6).

\section{Diagnostic antituberculosis therapy and follow-up of pathologically undiagnosed ET}

No patients were confirmed by pathological diagnosis; however, the pathological findings may exclude tumours and provide a reference for subsequent treatment. However, we first considered ET based on EUS examination, and when combined with the clinical manifestations mentioned above, the patients subsequently received 
Table 1 Clinical features and Histopathologic findings of undiagnosed ET

\begin{tabular}{|c|c|c|c|c|c|c|c|}
\hline Case No. & Age/Sex & Presentation (duration) & Medical history & $\operatorname{ESR}(\mathrm{mm} / \mathrm{h})$ & $\begin{array}{l}\text { PPD test } \\
\text { or T-SPOT }\end{array}$ & Chest CT (or Esophagography) & Histopathologic findings \\
\hline 1 & $41 / F$ & $\begin{array}{l}\text { Retrosternal discomfort } \\
(4 \mathrm{wk})\end{array}$ & Normal & 15 & $\mathrm{PPD}(+++)$ & $\begin{array}{l}\text { Pulmonary fibrosis in right } \\
\text { lower lobe }\end{array}$ & $\begin{array}{l}\text { Chronic inflammation with } \\
\text { suspected epithelioid cells } \\
\text { (routine + deep biopsy) }\end{array}$ \\
\hline 2 & $57 / M$ & Dysphagia (4 wk) & Normal & 7 & T-SPOT (+) & $\begin{array}{l}\text { A few fibrotic foci in the right } \\
\text { lung }\end{array}$ & $\begin{array}{l}\text { Chronic inflammation } \\
\text { (multipoint biopsy) }\end{array}$ \\
\hline 3 & $50 / F$ & $\begin{array}{l}\text { Dysphagia and } \\
\text { retrosternal pain ( } 6 \text { wk) }\end{array}$ & $\begin{array}{l}\text { Pulmonary } \\
\text { tuberculosis }\end{array}$ & 30 & $\operatorname{PPD}(++++)$ & $\begin{array}{l}\text { Bilateral secondary pulmonary } \\
\text { tuberculosis, with increased } \\
\text { mediastinal lymph nodes }\end{array}$ & $\begin{array}{l}\text { Chronic inflammation with } \\
\text { acute inflammation } \\
\text { (multipoint biopsy) }\end{array}$ \\
\hline 4 & $35 / M$ & $\begin{array}{l}\text { Dysphagia and } \\
\text { retrosternal pain ( } 9 \text { wk) }\end{array}$ & $\begin{array}{l}\text { Pulmonary } \\
\text { tuberculosis }\end{array}$ & 28 & $\operatorname{PPD}(+++)$ & $\begin{array}{l}\text { Secondary pulmonary } \\
\text { tuberculosis in the right upper } \\
\text { lobe, with enlargement of } \\
\text { mediastinal and left hilar } \\
\text { lymph nodes }\end{array}$ & $\begin{array}{l}\text { Chronic inflammation } \\
\text { (routine biopsy + EUS-FNA) }\end{array}$ \\
\hline 5 & $47 / M$ & $\begin{array}{l}\text { Retrosternal } \\
\text { discomfort } \\
(4 \mathrm{wk})\end{array}$ & Gastric ulcer & 10 & T-SPOT (+) & $\begin{array}{l}\text { A small amount of proliferation } \\
\text { and fibrosis foci in the bilateral } \\
\text { lungs }\end{array}$ & $\begin{array}{l}\text { Chronic inflammation with } \\
\text { acute inflammation } \\
\text { (routine + deep biopsy) }\end{array}$ \\
\hline 6 & $47 / F$ & $\begin{array}{l}\text { Retrosternal discomfort } \\
(4 \mathrm{wk})\end{array}$ & $\begin{array}{l}\text { Pulmonary } \\
\text { tuberculosis }\end{array}$ & 6 & T-SPOT (+) & $\begin{array}{l}\text { A few fibrotic foci in the right } \\
\text { lung, right pleural thickening }\end{array}$ & $\begin{array}{l}\text { Chronic inflammation } \\
\text { (routine + deep biopsy) }\end{array}$ \\
\hline 7 & $38 / F$ & $\begin{array}{l}\text { Retrosternal discomfort } \\
(2 \mathrm{wk})\end{array}$ & Normal & 5 & T-SPOT (+) & $\begin{array}{l}\text { A few fibrotic foci in the } \\
\text { bilateral lungs } \\
\text { (Esophagography: esophageal } \\
\text { diverticulum) }\end{array}$ & Not acquired \\
\hline 8 & $59 / F$ & $\begin{array}{l}\text { Dysphagia } \\
(4 \mathrm{wk})\end{array}$ & $\begin{array}{l}\text { Pulmonary } \\
\text { tuberculosis }\end{array}$ & 15 & T-SPOT (+) & $\begin{array}{l}\text { Multiple calcifications in the } \\
\text { bilateral lungs and mediastinum, } \\
\text { suspicious esophago- } \\
\text { mediastinal fistula }\end{array}$ & $\begin{array}{l}\text { Chronic inflammation } \\
\text { (multipoint biopsy) }\end{array}$ \\
\hline 9 & $29 / F$ & Dysphagia (2 wk) & Normal & 9 & $\operatorname{PPD}(+++)$ & $\begin{array}{l}\text { A few fibrotic foci in bilateral } \\
\text { lungs }\end{array}$ & $\begin{array}{l}\text { Chronic inflammation } \\
\text { (multipoint biopsy) }\end{array}$ \\
\hline
\end{tabular}

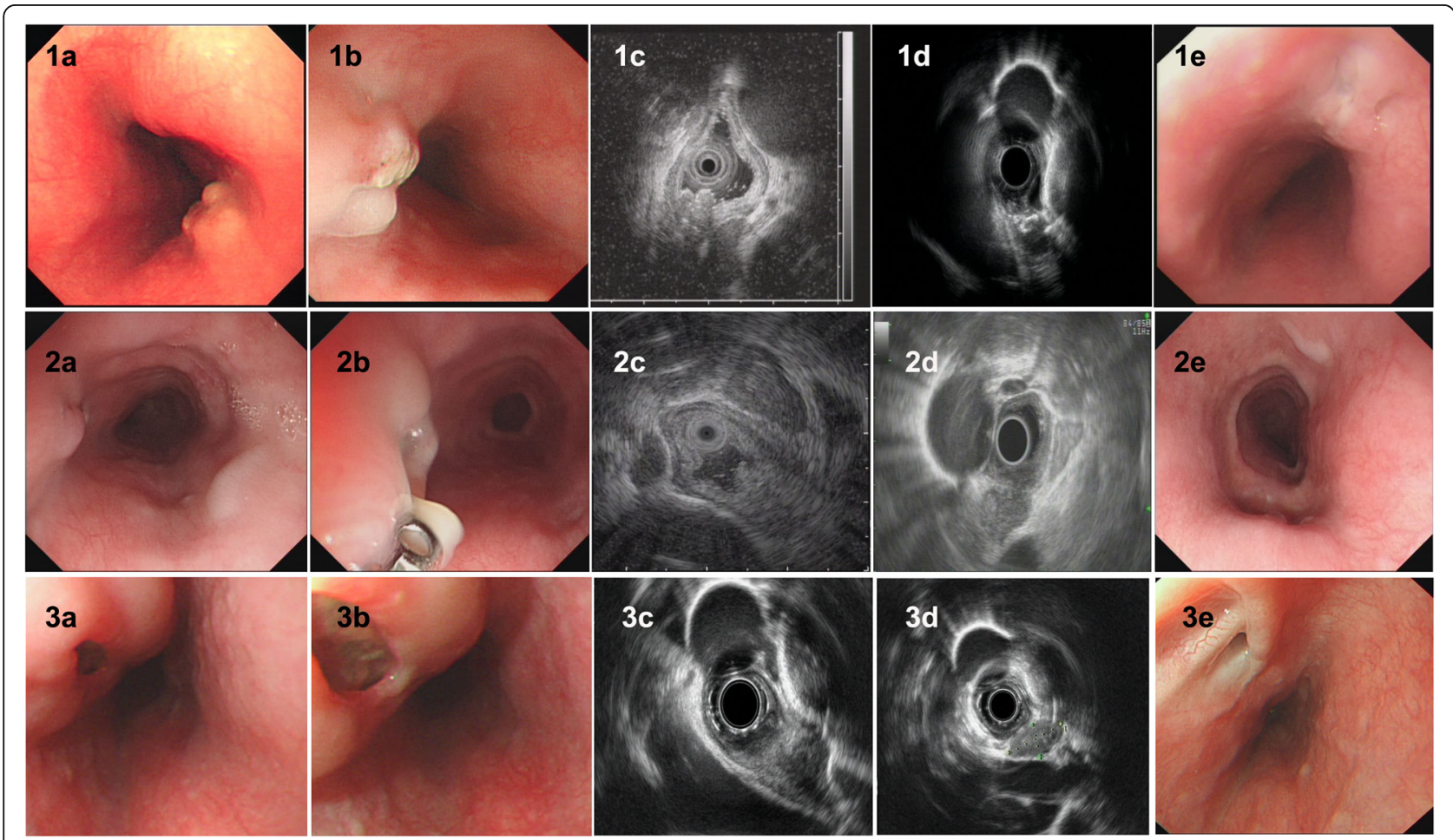

Fig. 1 Esophagoscopic findings and EUS features of pathologically undiagnosed ET (cases 1-3). 1-3, case 1-3. a (far view) and b (near view) Esophagoscopy: a protruding lesion in the mucosa with a central ulcer. $\mathbf{c}$ and $\mathbf{d}$, EUS: thickening, poorly defined esophageal wall structure, with one or more enlarged paraesophageal lymph nodes. e, repeat esophagoscopy after treatment: a white mucosal depression with scar formation 


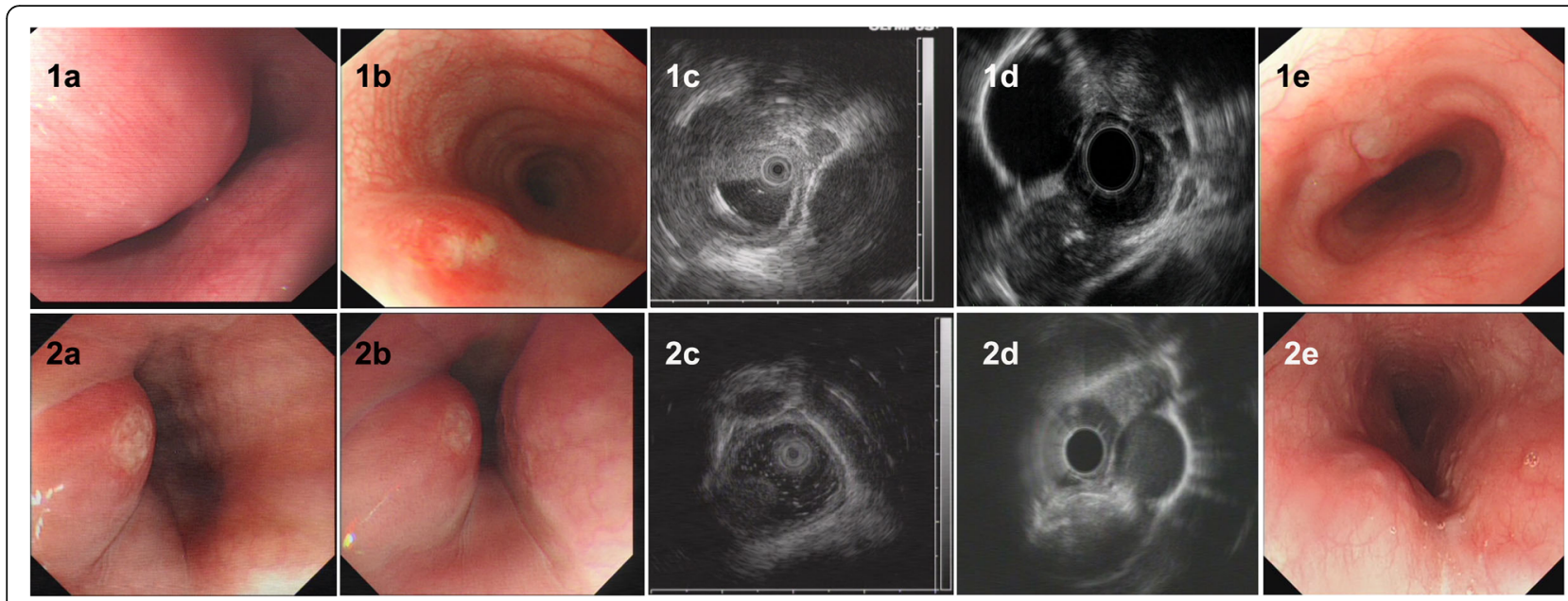

Fig. 2 Esophagoscopic findings and EUS features of pathologically undiagnosed ET (cases 4 and 5). 1, case 4; 2, case 5. a (far view) and b (near view) Esophagoscopy: a protruding lesion in the mucosa with central erosion. $\mathbf{c}$ and $\mathbf{d}$, EUS: thickening, poorly defined esophageal wall structure, with (case 4) or without (case 5) enlarged paraesophageal lymph nodes. e, repeat esophagoscopy after treatment: a white mucosal depression with scar formation (case 4) and the protruding lesion in the mucosa became smaller with disappearance of erosion (case 5)

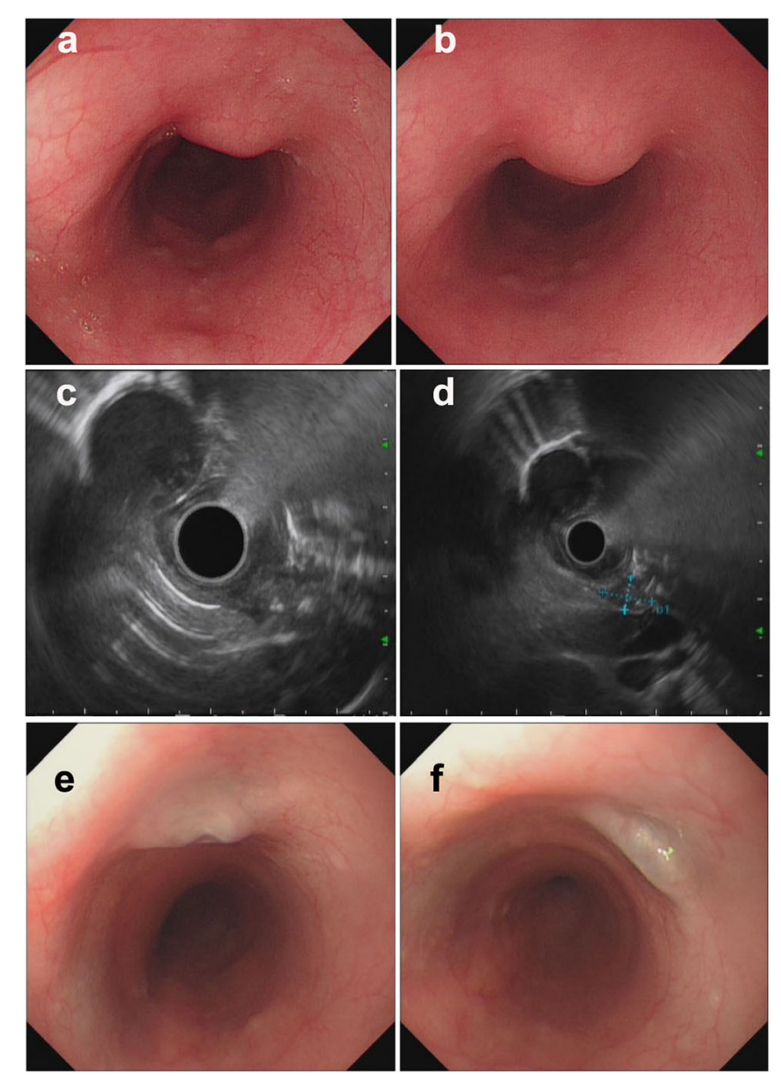

Fig. 3 Esophagoscopic findings and EUS features of pathologically undiagnosed ET (case 6). a (far view) and $\mathbf{b}$ (near view) Esophagoscopy: a submucosal bulge with smooth surface. $\mathbf{c}$ and $\mathbf{d}$ EUS: thickening, poorly defined esophageal wall structure, linked to an enlarged paraesophageal lymph node, with scattered calcifications. e and $\mathbf{f}$, repeat esophagoscopy after treatment: a white mucosal depression with scar formation diagnostic antituberculosis therapy. After treatment with a quadruple standard dose of antituberculosis drugs (isoniazid + rifampicin + pyrazinamide + ethambutol) (the timing of medical treatment is shown in Table 2), the patients all (100\%) recovered (cases 1-4, 6, 8 and 9; Fig. 1. 1-3e, Fig. 2. 1e, Fig. 3 e and f, Fig. 5 f and Fig. 6 f) or improved (cases 5 and 7, Fig. 2. 2e and Fig. 4f), with follow-up times ranging from 3 to 10 months. Surprisingly, seven patients, accounting for $77.8 \%$ of patients, achieved endoscopic recovery within six months, leaving white mucosal depressions with scar formation, which were observed by repeat endoscopy after treatment. (Table 2 and Fig. 1, 2, 3, 4, 5, and 6).

\section{Discussion}

ET is relatively rare. The clinical features of ET are often atypical, so these patients are easily misdiagnosed or often receive delayed diagnoses [8]; additionally, some patients undergo unnecessary esophagectomy, because malignancy cannot be ruled out [9], and some patients are even misdiagnosed with esophageal cancer [10], which causes substantial physical pain and economic losses. In clinical practice, although the diagnostic technology for ET has been improved, some patients with ET still cannot be diagnosed by repeated biopsies. In our hospital from January 2011 to December 2018, there were 23 cases of esophageal tuberculosis confirmed by biopsies (caseous necrotizing granuloma and/or acid-fast bacilli), including 3 cases confirmed by routine biopsy, 6 cases by multipoint biopsy, 12 cases by deep biopsy, and 2 cases by EUS-FNA. However, pathologically undiagnosed ET accounted for 28.1\% (9/32) of all cases. The 


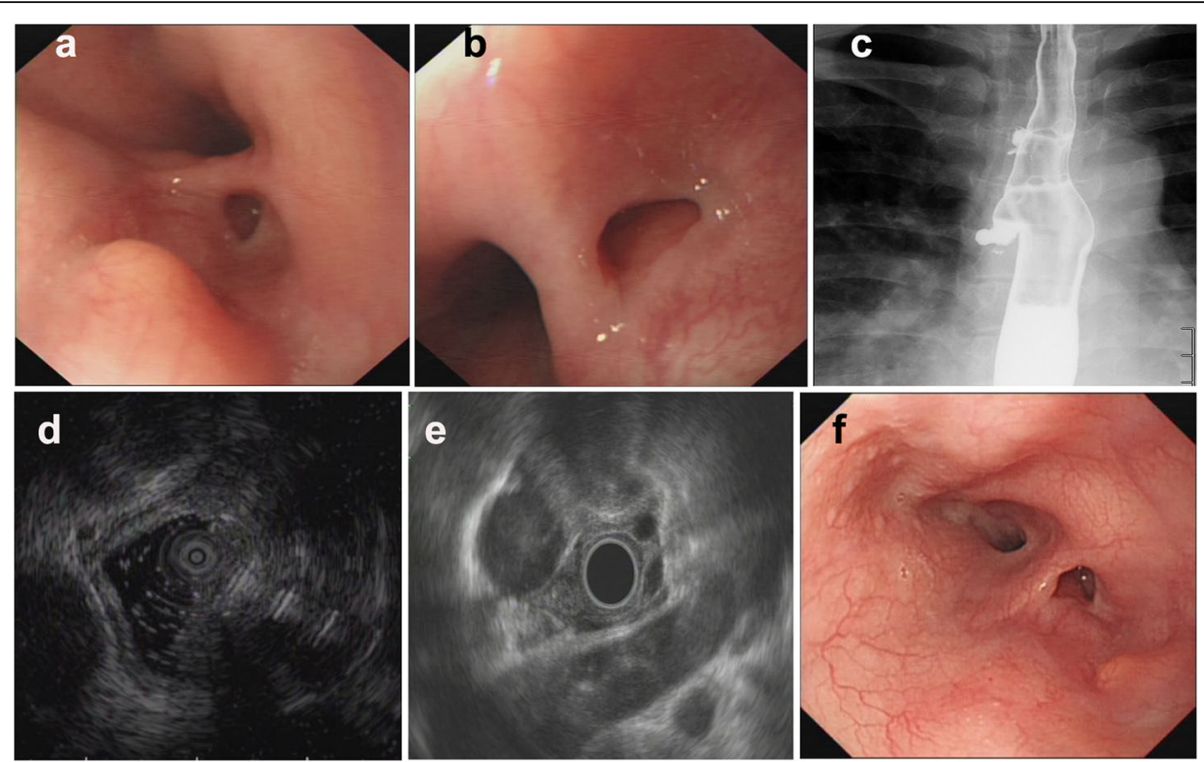

Fig. 4 Esophagoscopic findings and EUS features of pathologically undiagnosed ET (case 7). a (far view) and b (near view) Esophagoscopy: a submucosal bulge and diverticulum. c, Esophagography: a diverticulum formation. $\mathbf{d}$ and e, EUS: thickening, poorly defined esophageal wall structure, with enlarged paraesophageal lymph nodes. f, repeat esophagoscopy after treatment: the submucosal bulge became smaller

purpose of this study was to summarize the clinical manifestations and EUS features of ET by retrospectively analysing patients with pathologically undiagnosed ET, to improve the understanding of ET and reduce clinical misdiagnosis.

On esophagoscopy, the endoscopic findings of ET are varied, such as mucosal or submucosal eminence lesion, ulcer, diverticulum and fistula formation $[11,12]$. In addition, esophagography and chest CT can only provide indirect esophageal images (although chest CT can also visualize changes from pulmonary tuberculosis). Therefore, it is difficult for physicians to judge the disease as ET from the above findings. In addition, none of the patients we discussed received a confirmed

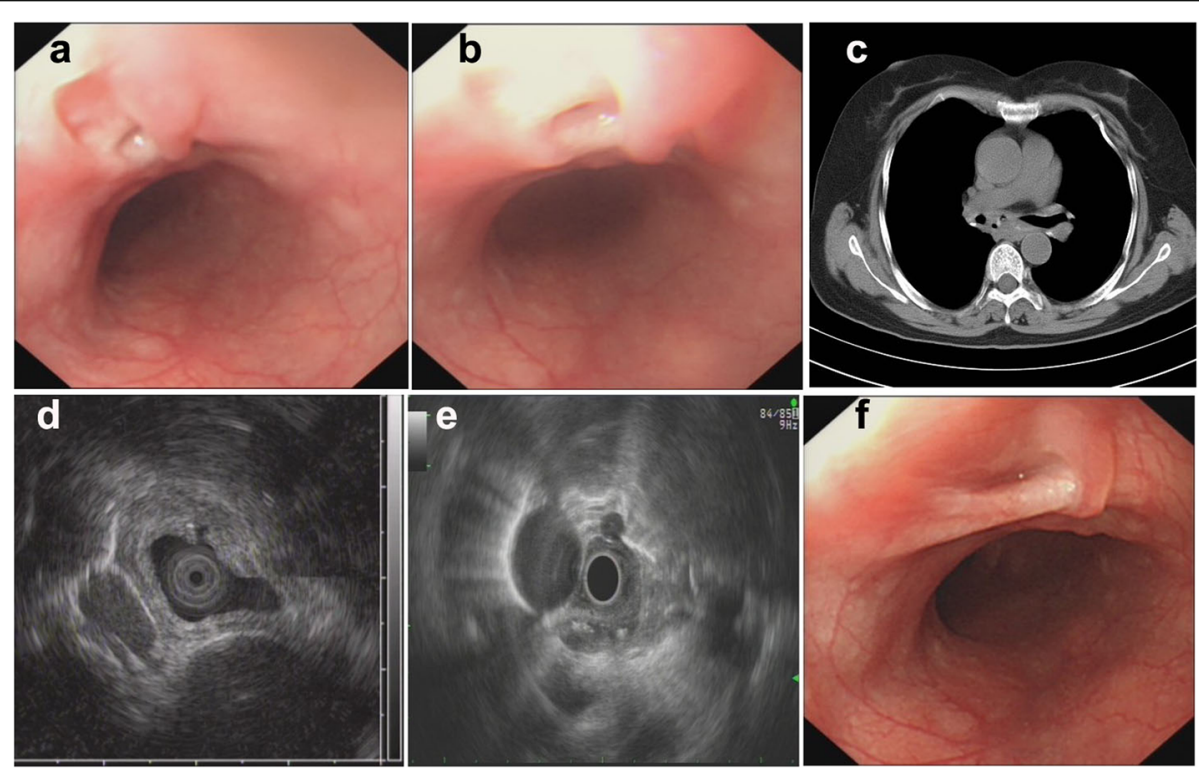

Fig. 5 Esophagoscopic findings and EUS features of pathologically undiagnosed ET (case 8). a (far view) and b (near view) Esophagoscopy: an ulcer with suspicious fistula formation. c, chest CT: a small amount of bubbles and fluid in the mediastinum around the esophagus. $\mathbf{d}$ and $\mathbf{e}$, EUS: thickening, poorly defined esophageal wall structure, with one or more enlarged paraesophageal lymph nodes. $\mathbf{f}$, repeat esophagoscopy after treatment: a white mucosal depression with scar formation 


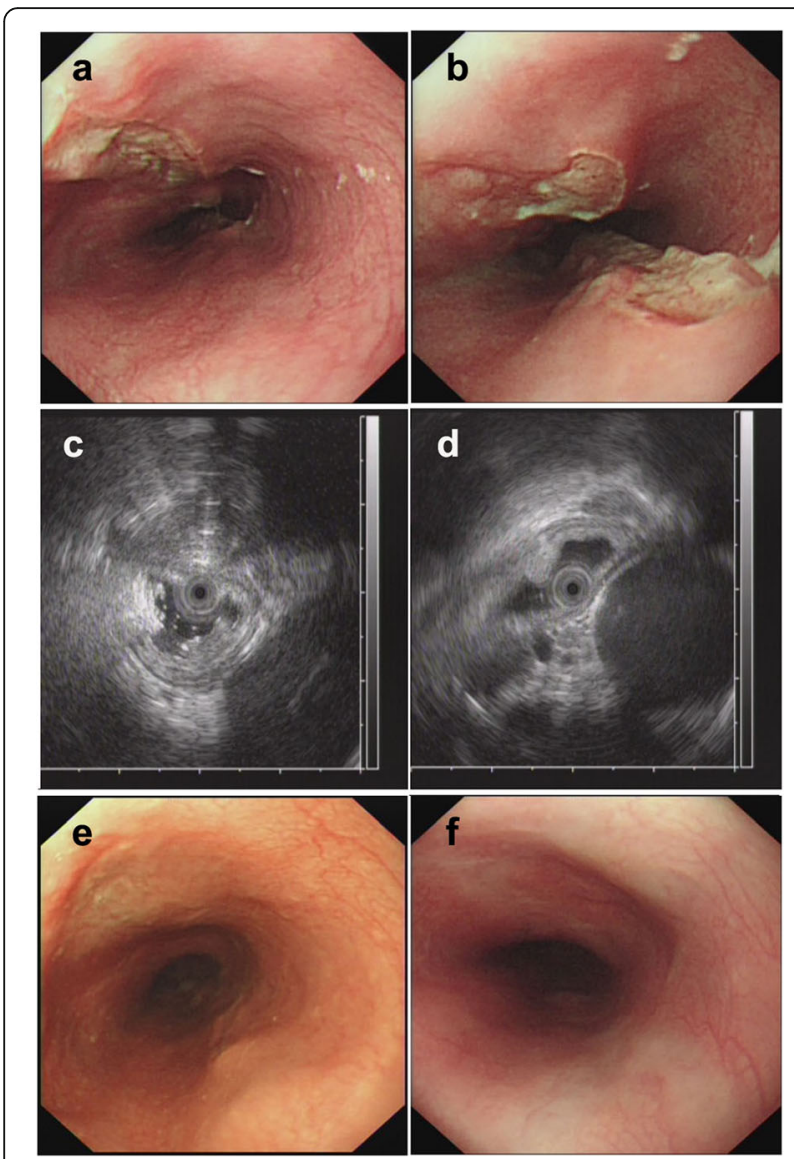

Fig. 6 Esophagoscopic findings and EUS features of pathologically undiagnosed ET (case 9). a (far view) and $\mathbf{b}$ (near view) Esophagoscopy: multiple ulcers. c and d, EUS: Thickening, poorly defined esophageal wall structure, with an enlarged paraesophageal lymph node. e, repeat esophagoscopy 2 months after treatment: the ulcers improved. f, repeat esophagoscopy 4 months after treatment: white mucosal depressions with scar formation

histopathological or bacteriological diagnosis by pathology after at least two biopsies (including routine biopsy, multipoint or deep biopsy, and even EUS-FNA). For pathologically undiagnosed ET, EUS has unique advantages because it can show lesions in and outside the esophageal wall, which is especially helpful for differentiation from esophageal cancer. Many patients can finally be diagnosed by EUS-FNA. Esophageal cancer mainly manifest as mucosal lesions, which then invade the submucosa, surrounding lymph nodes and other tissues and organs, while ET is mainly caused by the invasion of tuberculosis into paraesophageal or mediastinal lymph nodes, and some patients have tuberculosis in other parts of the body. Here we summarized the EUS features of ET as follows: (1) thickening, poorly defined esophageal wall structure, and interrupted partial esophageal adventitia; (2) hypoechoic lesion in the esophageal wall, with an irregular boundary and nonhomogeneous inner echogenicity, or with scattered hyperechoic calcifications; (3) enlarged paraesophageal or mediastinal lymph nodes or some with scattered calcifications; and (4) in some patients, lesions of esophageal wall that are linked to the enlarged paraesophageal lymph nodes. The EUS features of ET confirmed by biopsies in our hospital are consistent with those of undiagnosed ET reported in our article. Some of the above EUS features have been reported in the literature (such as heterogeneous or homogeneous hypoechoic masses, interruption of the esophageal adventitia, and enlarged mediastinal lymph nodes [13, 14]). Of the four features, the fourth feature is especially important because it suggests that tuberculosis of the paraesophageal lymph nodes spread directly to the esophagus [15].

In summary, there are three types of mode of involvement of ET according to the method of infection [3, 5]: Type 1, secondary ET, is the most common type and is often secondary to tuberculosis in adjacent organs and tissues, such as paraesophageal or mediastinal lymph node tuberculosis; paraesophageal lesions of the esophagus have often been missed in the pre-EUS era. Puri $R$ et al. [16] showed that ET was commonly secondary to mediastinal lymph nodal involvement in 32 cases of ET, and EUS showed lymph nodes adjacent to esophageal pathology in all cases. In our study, 88.9\% (8/9) of patients had one or more enlarged paraesophageal lymph nodes, and $50 \%(4 / 8)$ in the lesions of esophageal wall were linked to enlarged paraesophageal lymph nodes. Therefore, our study focuses on secondary esophageal tuberculosis. Type 2, primary ET, occurs when food or sputum containing Mycobacterium tuberculosis is swallowed; Mycobacterium tuberculosis adheres to the esophageal mucosa and causes tuberculosis infection, especially when the esophageal mucosa is damaged. Because the esophageal mucosa is composed of squamous epithelial cells covered with saliva and mucus, which have very good protective effects for the esophagus, this type is rare. Type 3, haematogenous disseminated ET, is often seen in patients with severe tuberculosis, and is very rare.

ET may occur in any part of the esophagus, but occurs mainly in the middle part, which is consistent with the literature $[17,18]$. The common clinical features are retrosternal pain or discomfort, or (and) dysphagia. Typical tuberculosis poisoning is often absent. Some patients may have a history of tuberculosis in other parts of the body (mostly pulmonary tuberculosis). PPD test or T-SPOT.TB, ESR, chest CT, and esophagography may have certain reference value in the diagnosis of ET [19]. Esophageoscopic findings lack specificity, and pathological biopsies are sometimes disappointing; falsenegative results often occur due to the failure to obtain 
Table 2 Endoscopic findings, EUS features, treatment and prognosis of undiagnosed ET

\begin{tabular}{|c|c|c|c|c|}
\hline CaseNo. & Esophagoscopy findings & EUS features & $\begin{array}{l}\text { Diagnostic anti- } \\
\text { tuberculosis therapy }\end{array}$ & Prognosis \\
\hline 1 & $\begin{array}{l}\text { Middle part of esophagus, protruding } \\
\text { lesion in the mucosa } 0.8 \times 3.0 \mathrm{~cm} \text { with } \\
\text { a central ulcer } 0.3 \times 0.5 \mathrm{~cm}\end{array}$ & $\begin{array}{l}\text { Thickening, poorly defined esophageal } \\
\text { wall structure, enlarged para esophageal } \\
\text { lymph nodes with scattered calcifications }\end{array}$ & $\begin{array}{l}\text { Isoniazid + rifampicin }+ \\
\text { pyrazinamide + ethambutol, } \\
3 \text { months }\end{array}$ & $\begin{array}{l}\text { Recovered according } \\
\text { to endoscopy }\end{array}$ \\
\hline 2 & $\begin{array}{l}\text { Middle part of esophagus, protruding } \\
\text { lesion in the mucosa } 1.5 \times 2.0 \mathrm{~cm} \text { with } \\
\text { a central ulcer } 0.2 \times 0.3 \mathrm{~cm}\end{array}$ & $\begin{array}{l}\text { Thickening, poorly defined esophageal } \\
\text { wall structure, linked to an enlarged para } \\
\text { esophageal lymph node }\end{array}$ & $\begin{array}{l}\text { Isoniazid + rifampicin }+ \\
\text { pyrazinamide + ethambutol, } \\
3 \text { months }\end{array}$ & $\begin{array}{l}\text { Recovered according } \\
\text { to endoscopy }\end{array}$ \\
\hline 3 & $\begin{array}{l}\text { Middle part of esophagus, protruding } \\
\text { lesion in the mucosa } 2.0 \times 3.0 \mathrm{~cm} \text { with } \\
\text { a central ulcer } 0.5 \times 0.8 \mathrm{~cm}\end{array}$ & $\begin{array}{l}\text { Thickening, poorly defined esophageal } \\
\text { wall structure, with an enlarged para } \\
\text { esophageal lymph node }\end{array}$ & $\begin{array}{l}\text { Isoniazid + rifampicin + } \\
\text { pyrazinamide + ethambutol, } \\
10 \text { months }\end{array}$ & $\begin{array}{l}\text { Recovered according } \\
\text { to endoscopy }\end{array}$ \\
\hline 4 & $\begin{array}{l}\text { Middle part of esophagus, protruding } \\
\text { lesion in the mucosa } 2.5 \times 3.0 \mathrm{~cm} \text { with } \\
\text { central erosion } 0.3 \times 0.4 \mathrm{~cm}\end{array}$ & $\begin{array}{l}\text { Thickening, poorly defined esophageal } \\
\text { wall structure, esophageal } \\
\text { heterogeneously hypoechoic lesion with } \\
\text { scattered calcifications, and the } \\
\text { hypoechoic lesion was linked to an } \\
\text { enlarged para-esophageal lymph node }\end{array}$ & $\begin{array}{l}\text { Isoniazid + rifampicin }+ \\
\text { pyrazinamide + ethambutol, } \\
5 \text { months }\end{array}$ & $\begin{array}{l}\text { Recovered according } \\
\text { to endoscopy }\end{array}$ \\
\hline 5 & $\begin{array}{l}\text { Lower part of esophagus, protruding } \\
\text { lesion in the mucosa } 1.0 \times 1.5 \mathrm{~cm} \text { with } \\
\text { central erosion, } 0.2 \times 0.2 \mathrm{~cm}\end{array}$ & $\begin{array}{l}\text { Thickening, poorly defined esophageal } \\
\text { wall structure, with heterogeneously } \\
\text { hypoechoic esophageal lesion, and } \\
\text { interrupted partial esophageal adventitia }\end{array}$ & $\begin{array}{l}\text { Isoniazid + rifampicin + } \\
\text { pyrazinamide + ethambutol, } \\
4 \text { months }\end{array}$ & $\begin{array}{l}\text { Improved according } \\
\text { to endoscopy }\end{array}$ \\
\hline 6 & $\begin{array}{l}\text { Middle part of esophagus, submucosal } \\
\text { bulge } 0.8 \times 1.0 \mathrm{~cm} \text { with smooth surface }\end{array}$ & $\begin{array}{l}\text { Thickening, poorly defined esophageal } \\
\text { wall structure } \\
\text { linked to an enlarged para-esophageal } \\
\text { lymph node, with scattered calcifications }\end{array}$ & $\begin{array}{l}\text { Isoniazid + rifampicin + } \\
\text { pyrazinamide + ethambutol, } \\
5 \text { months }\end{array}$ & $\begin{array}{l}\text { Recovered according } \\
\text { to endoscopy }\end{array}$ \\
\hline 7 & $\begin{array}{l}\text { Upper part of esophagus, submucosal } \\
\text { bulge } 0.5 \times 0.7 \mathrm{~cm} \text {, and diverticulum }\end{array}$ & $\begin{array}{l}\text { Thickening, poorly defined esophageal } \\
\text { wall structure, with enlarged } \\
\text { para-esophageal lymph nodes }\end{array}$ & $\begin{array}{l}\text { Isoniazid + rifampicin + } \\
\text { pyrazinamide + ethambutol, } \\
9 \text { months }\end{array}$ & $\begin{array}{l}\text { Improved according } \\
\text { to endoscopy }\end{array}$ \\
\hline 8 & $\begin{array}{l}\text { Middle part of esophagus, irregular } \\
\text { ulcer } 0.3 \times 0.5 \mathrm{~cm} \text {, with fistula }\end{array}$ & $\begin{array}{l}\text { Thickening, poorly defined esophageal } \\
\text { wall structure } \\
\text { linked to an enlarged para-esophageal } \\
\text { lymph node with scattered calcifications }\end{array}$ & $\begin{array}{l}\text { Isoniazid + rifampicin + } \\
\text { pyrazinamide + ethambutol, } \\
6 \text { months }\end{array}$ & $\begin{array}{l}\text { Recovered according } \\
\text { to endoscopy }\end{array}$ \\
\hline 9 & $\begin{array}{l}\text { Middle part of esophagus, multiple } \\
\text { ulcers } 0.3 \times 0.5 \mathrm{~cm}-0.5 \times 0.6 \mathrm{~cm}\end{array}$ & $\begin{array}{l}\text { Thickening, poorly defined esophageal } \\
\text { wall structure, with an enlarged } \\
\text { para-esophageal lymph node }\end{array}$ & $\begin{array}{l}\text { Isoniazid + rifampicin }+ \\
\text { pyrazinamide + ethambutol, } \\
4 \text { months }\end{array}$ & $\begin{array}{l}\text { Recovered according } \\
\text { to endoscopy }\end{array}$ \\
\hline
\end{tabular}

definite caseous necrotizing granuloma and acid-fast bacilli. Therefore, the diagnosis of ET has always been a great challenge in clinical work [20].

For pathologically undiagnosed ET, EUS has the advantage of combining ultrasonography with endoscopy and can show some features of ET. Although biopsies (including EUS-FNA) are sometimes negative, we can first consider the diagnosis of ET based on EUS examination, and exclude tumours though pathology; when EUS features are combined with clinical features, we can consider experimental anti-tuberculosis treatment [19] for ET patients and finally make a definite diagnosis according to treatment effect. In addition, when EUS is used as the initial examination for patients, the characteristics summarized in this paper can be sufficient to help establish our initial diagnosis. However, in clinical work, we should try our best to obtain the gold standard diagnosis (caseous necrotizing granuloma and acid-fast bacilli), and the side effects of anti-tuberculosis drugs should be monitored throughout the course of diagnostic therapy and treatment.

\section{Conclusions}

EUS is an important diagnostic tool for ET, because it can show the lesions in and outside the esophageal wall by endoscopy combined with ultrasonography. In this study, We summarized some significant EUS features of $\mathrm{ET}$, to improve the understanding of ET and reduce clinical misdiagnosis.

\section{Abbreviations \\ EUS: Endoscopic ultrasonography; ET: Esophageal tuberculosis; ESR: Erythrocyte sedimentation rate; CT: Computerized tomography; PPD: Purified protein derivative; T-SPOT TB: T cell spot test for tuberculosis infection; EUS-FNA: Endoscopic ultrasonography-guided fine-needle aspiration}

\section{Acknowledgements}

Not applicable.

\section{Authors' contributions}

Conception and design: RZ, HCW; Acquisition of data: YKZ, XGF, YHB; Analysis and Interpretation of data: KZ, BGT; Drafting of the manuscript: RZ; Critical revision of the manuscript for important intellectual content: HCW; Statistical analysis: RZ, HCW. All authors have read and approved the final manuscript for publication. 


\section{Funding}

The authors declare that they received no specific grants from any funding agency in the public, commercial or not-for-profit sectors.

\section{Availability of data and materials}

All data analysed during this study are included in this manuscript (Table 1 and Table 2).

\section{Ethics approval and consent to participate}

We have read and abided by the statement of ethical standards for manuscripts submitted to BMC gastroenterology. The Ethics Committee of the Affiliated Hospital of Zunyi Medical University approved this retrospective study. Our access to the data used in this study was approved by the Ethics Committee. Verbal informed consent was obtained from each patient, and the Ethics Committee approved this procedure. Since this is a retrospective study, a waiver of written informed consent was obtained from the Ethics Committee.

\section{Consent for publication}

Written informed consent for publication was obtained from all patients. Copies of the consent forms containing personal or clinical details or any identifying images published in this study are available upon request.

\section{Competing interests}

The authors declare that they have no competing interests.

\section{Author details}

'Department of Gastroenterology, Affiliated Hospital, Zunyi Medical University, Zunyi 563003, China. ${ }^{2}$ Department of Pathology, Affiliated Hospital, Zunyi Medical University, Zunyi 563003, China.

Received: 1 April 2020 Accepted: 20 August 2020

Published online: 28 August 2020

\section{References}

1. Lockard LB. Oesophageal tuberculosis: a critical review. Laryngoscope. 1913; 23:561-84

2. Carr DT, Spain DM. Tuberculosis in a carcinoma of the esophagus. Am Rev Tubercul. 1942;46:346-9.

3. Jain SK, Jain S, Jain M, et al. Esophageal tuberculosis: is it so rare? Report of 12 cases and review of the literature. Am J Gastroenterol. 2002;97(2):287-94.

4. Rana SS, Mandavdhare $H$, Sharma V, et al. Successful closure of chronic, nonhealing tubercular esophagobronchial fistula with an over-the-scope clip. J Digestive Endoscopy. 2017;8(1):33-5.

5. Dahale AS, Kumar A, Srivastava S, et al. Esophageal tuberculosis: uncommon of common. JGH Open. 2018;2(2):34-8.

6. Ni BQ, Lu XH, Gong QX, et al. Surgical outcome of esophageal tuberculosis secondary to mediastinal lymphadenitis in adults: experience from single center in China. J Thorac Dis. 2013;5(4):498-505.

7. Tang Y, Shi W, Sun X, et al. Endoscopic ultrasound in diagnosis of esophageal tuberculosis: 10-year experience at a tertiary care center. Dis Esophagus. 2017;30(8):1-6.

8. Elosua González A, Macías Mendizábal E, Saldaña Dueñas C, et al. Esophageal tuberculosis: a cause of dysphagia we should be aware of Gastrointest Endosc. 2018;88(6):964-5.

9. Fujiwara $\mathrm{Y}$, Osugi $\mathrm{H}$, Takada N, et al. Esophageal tuberculosis presenting with an appearance similar to that of carcinoma of the esophagus. J Gastroenterol. 2003:38(5):477-81.

10. Khan MS, Maan MHA, Sohail AH, et al. Primary esophageal tuberculosis mimicking esophageal carcinoma on computed tomography: a case report. World J Gastrointest Surg. 2019;11(9):373-80.

11. Zhen $H$, Xiaoyun $W$, Lei $G$, et al. Esophageal tuberculosis presenting as a submucosal tumor. J Exp Clin Med. 2018;11(2):1226-32.

12. Yixuan $L$, Weiddong $N$, Huahong W. A case of esophageal tuberculosis with unusual endoscopic feature. Clin Res Hepatol Gastroenterol. 2018;42(1):e5-6.

13. Han XM, Yang JM, Xu LH, et al. Endoscopic ultrasonography in esophageal tuberculosis. Endoscopy. 2008:40:701-2.

14. Mou Y, Zeng HZ, Wang QM, et al. Esophageal tuberculosis initially misdiagnosed by endoscopy as a submucosal tumor. Endoscopy. 2015;47:E30-1.
15. Zhu R, Zhou Y, Wang H, et al. Gastric tuberculosis mimicking submucosal tumor: a case series. BMC Gastroenterol. 2020;20(1):23.

16. Puri R, Khaliq A, Kumar M, et al. Esophageal tuberculosis: role of endoscopic ultrasound in diagnosis. Dis Esophagus. 2012;25(2):102-6.

17. Park JH, Kim S, Sohn JW, et al. Endoscopic findings and clinical features of esophageal tuberculosis. Scand J Gastroenterol. 2010;45(11):1269-72.

18. Joana G, Ana A, Aurora C, et al. Dysphagia as a manifestation of esophageal tuberculosis: a report of two cases. J Med Case Rep. 2011;5:447.

19. Jong Hun S, Gwang Ha K, Joon Hyung J, et al. Endosonographic features of esophageal tuberculosis presenting as a subepithelial lesion. J Dig Dis. 2017; 18(3):185-8.

20. Samit SJ, Piyush OS, Rajeshkumar C. M et al. esophageal tuberculosis presenting with hematemesis. World J Gastrointest Endosc. 2013;5(11):581-3.

\section{Publisher's Note}

Springer Nature remains neutral with regard to jurisdictional claims in published maps and institutional affiliations.
Ready to submit your research? Choose BMC and benefit from:

- fast, convenient online submission

- thorough peer review by experienced researchers in your field

- rapid publication on acceptance

- support for research data, including large and complex data types

- gold Open Access which fosters wider collaboration and increased citations

- maximum visibility for your research: over $100 \mathrm{M}$ website views per year

At $\mathrm{BMC}$, research is always in progress.

Learn more biomedcentral.com/submissions 